\title{
Application of Electrical Resistivity in Buildings Foundation Investigation in Ibese Southwestern Nigeria
}

\section{Falae Philips Omowumi}

Geology Department, University of Ibadan, Nigeria

\begin{abstract}
Application of geophysical investigation has been carried out using Vertical Electrical Sounding (VES) at the proposed building site in Ibese Southwest Nigeria to determine the geophysical parameters that can be used to evaluate the structural competence of the subsurface geological characteristics of the site for construction purposes and building development. The Schlumberger configuration was used for the data acquisition. One-dimensional numerical inversion of individual DC resistivity was used to enhance the processing of the results for better achievement of the aim of the study. Models obtained from the 2D inversion of each VES were used for construction of geo-electric sections which exhibit the main geo-electric characteristics of the geological units present in the area. The interpretation results showed that the geoelectric sections consist of three-four layers namely: topsoil, pebble clay, limestone and sand/limestone. The layer resistivities and thicknesses range from 11 404 Ohm-m/0.4 - 1.5 m, 2-210 Ohm-m/ 0.8 - 9.2m and $33-160 \mathrm{Ohm}-\mathrm{m}$ respectively. The investigation revealed that the sand/limestone litho unit is to be the most competent for shallow foundation for small to medium engineering structures.
\end{abstract}

Keywords: Geophysical, building, geo-electric section, shallow foundation

\section{INTRODUCTION}

Foundation investigation is an important program in building and engineering structures. Several approaches have been used for the success of foundation investigations. Geophysical methods, particularly electrical resistivity technique, had been extensively used for a wide variety of engineering and environmental problems (Zohdy, 1975; Barker, 
1980; Boyce and Kaseoglu, 1996; Mousa, 2003, Olorunfemi, et al., 2004; Hosny et al., 2005; Alotaibi and Al-Amri, 2007; Nigm et al., 2008; Oyedele et al., 2009). The application of electrical resistivity survey has become a prime choice, as a result of the cheap cost that is involve and the fact that it saves time and easy to carry out, and can also be used to determine geological structures (Al-Sayed and El-Qady 2007). Engineering applications of electrical resistivity include investigation the bridge, dam and building structure foundations using electrical resistivity survey (Omoyoloye et al., 2008; Adeoti et al., 2009; Mahmoud; et al., 2009). Apart from engineering applications, electrical resistivity can also be of great importance in ground water investigation, determination of contamination source and impact of leachate. In this study, a non-destructive geophysical technique involving Vertical Electrical Sounding using Schlumberger array was adopted to investigate the subsurface conditions at the proposed building site in Ibese with the aim of determining the competency of the competent soil upon which the structure will be laid.

\section{Description of the Study Area}

Ibese town is about $4 \mathrm{~km}$ North of Ilaro town in Yewa North Local Government Area of Ogun state. The study area approximately bounded in the North by Longitude $07^{0}$

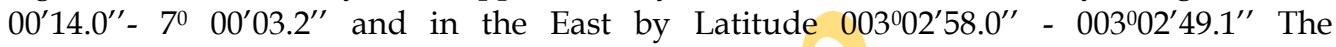
topography of the area is of relatively flat to a gentle slope terrain. The study area lies in Southern Nigeria, which is within the humid tropical region of the equatorial zone and is typified by two main climatic seasons, namely the wet and dry seasons. The area belongs to the tropical rainforest of southern Nigeria and is covered mainly by tall trees typical of savannah vegetation. The coastal swamp is mainly mangrove. The local geology of the study area (Fig.2) is that of Ewekoro formation.

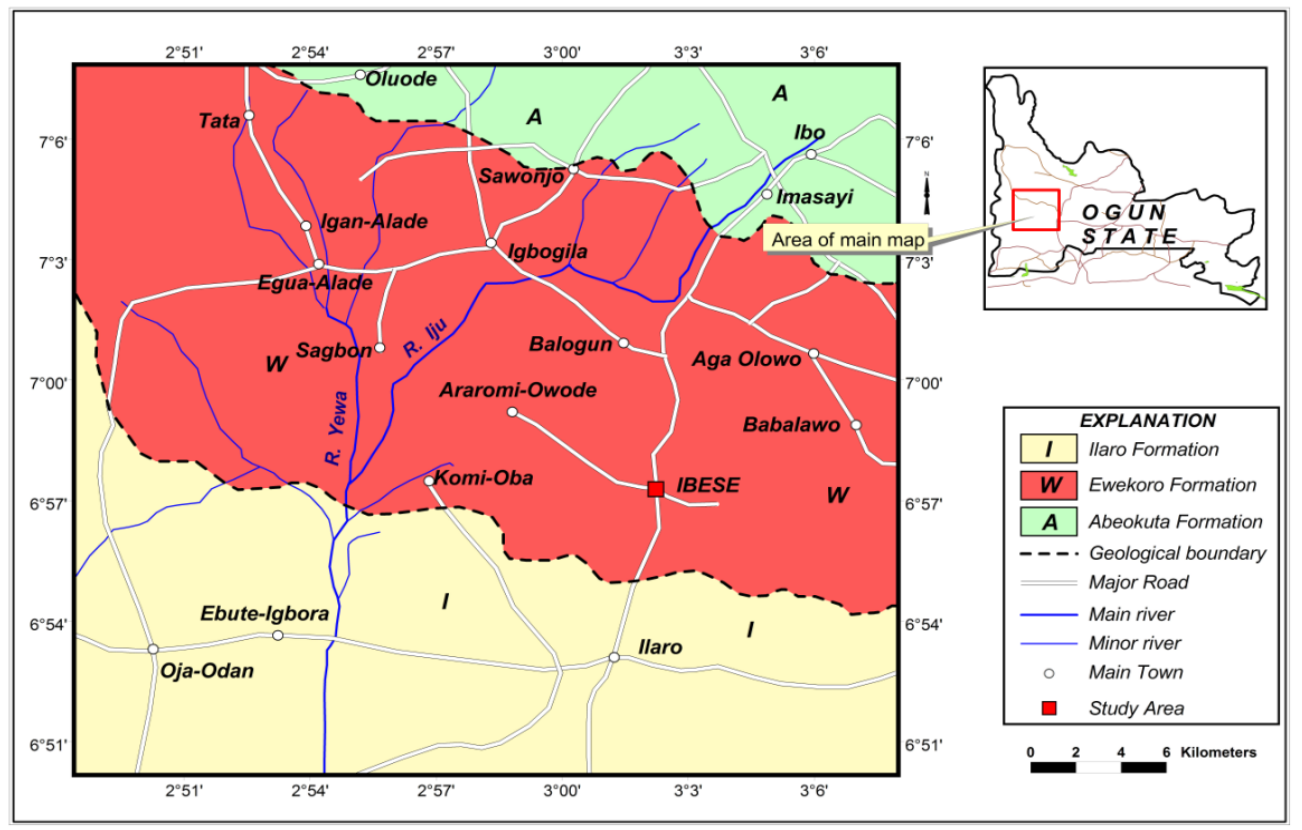

Figure 1, Geological map around Ibese showing the study area 


\section{Materials AND Methods}

Vertical Electrical Sounding (VES) using the Schlumberger electrode configuration (Fig 2) was carried out at fifteen (15) selected points within the study area (Fig.3). In all, fifteen VES points were located and fully occupied within the study area. The VES data obtained were subjected to partial curve matching using two-layer master curves and auxiliary curves as an initial stage of data interpretation (Orellana and Mooney, 1966; 1972). The layered earth model thus obtained served as the input model for the inversion algorithm as a final stage in the quantitative data interpretation (Zohdy, 1973; 1975 and 1989). The final interpreted results were used for the preparation of geo-electric sections and maps.

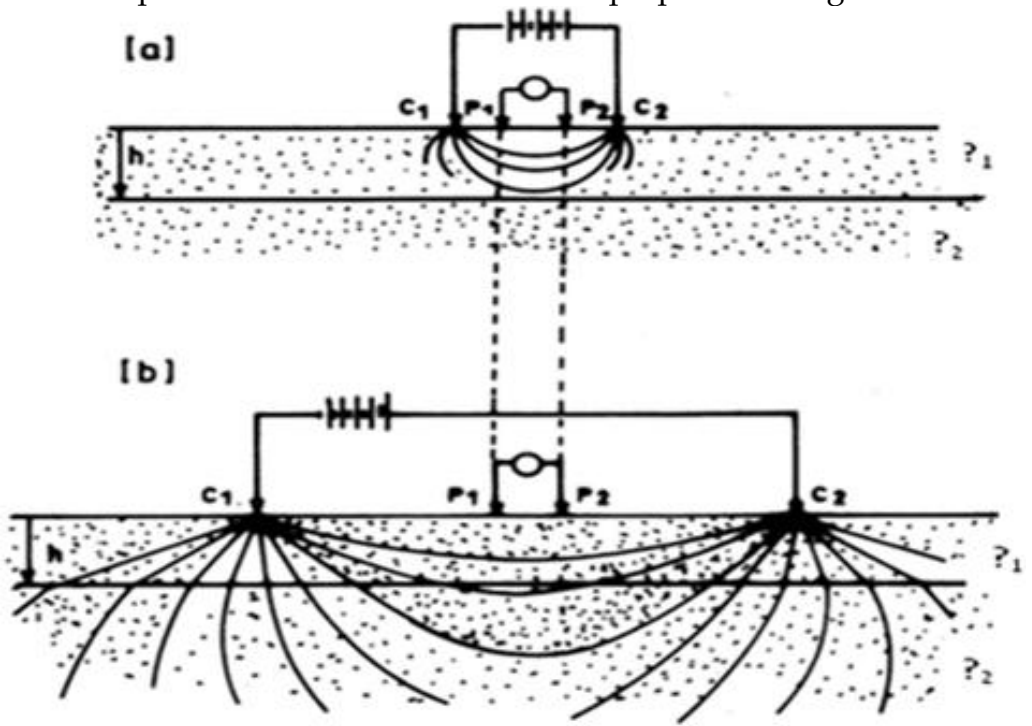

Figure 2, Principle of electric sounding (a) For small current electrode separation (b) For larger current electrode separation

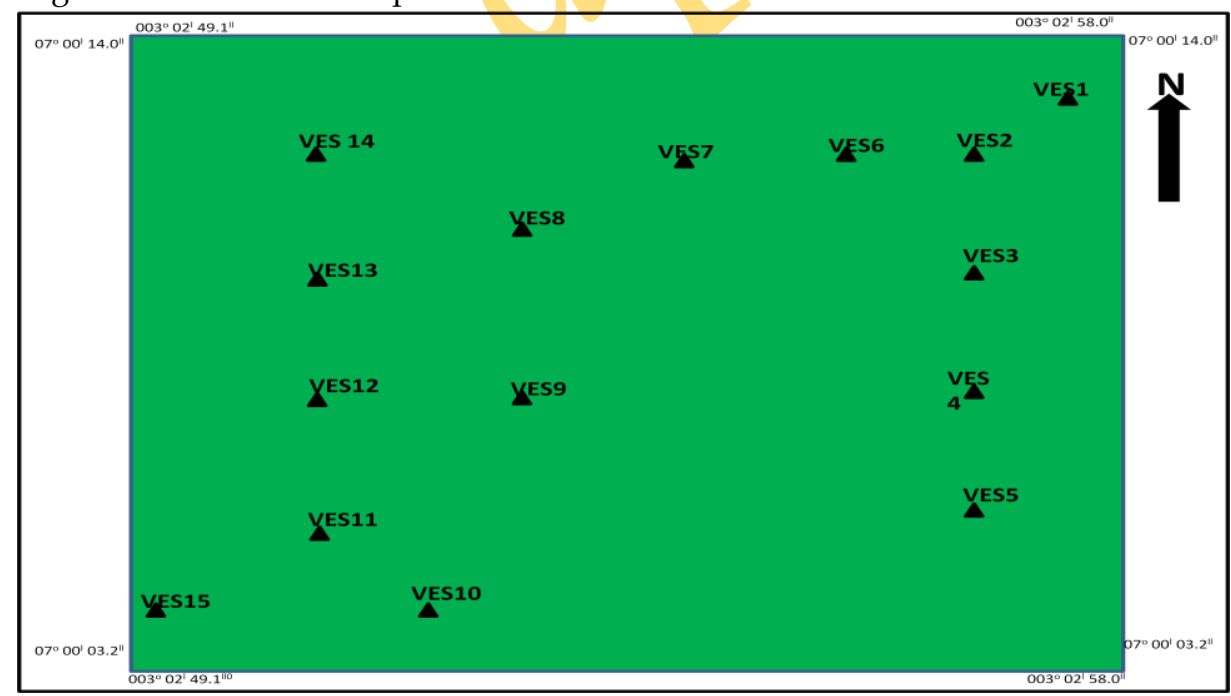

Figure 3: Spatial distribution of the VES point 


\section{RESULTS AND DISCUSSION}

The result of the geophysical survey is presented in Sounding Curves, Geo-electric sections and Maps. The layer model interpretations of all the VES points are presented in the figure $4 \mathrm{a}-4 \mathrm{o}$. The results of the interpretation show a system of three geo-electric layers for VES1-14 while VES15 shows a system of four geo-electric layers. All the curves show an $\mathrm{H}$ curve pattern. A summary of the VES interpretation is presented on Table 5.1. From the Table, it is quite evident that the resistivity of the first layer is very low indicating a high degree of saturation. The resistivity values range from $1.7-21 \mathrm{Ohm}-\mathrm{m}$ suggesting saturated clay/limestone unit. The thickness of this layer ranges from $6-9.2 \mathrm{~m}$. The second-layer shows a fairly saturated sandy/limestone unit with resistivity value ranging from 33-269.3 Ohm-m.
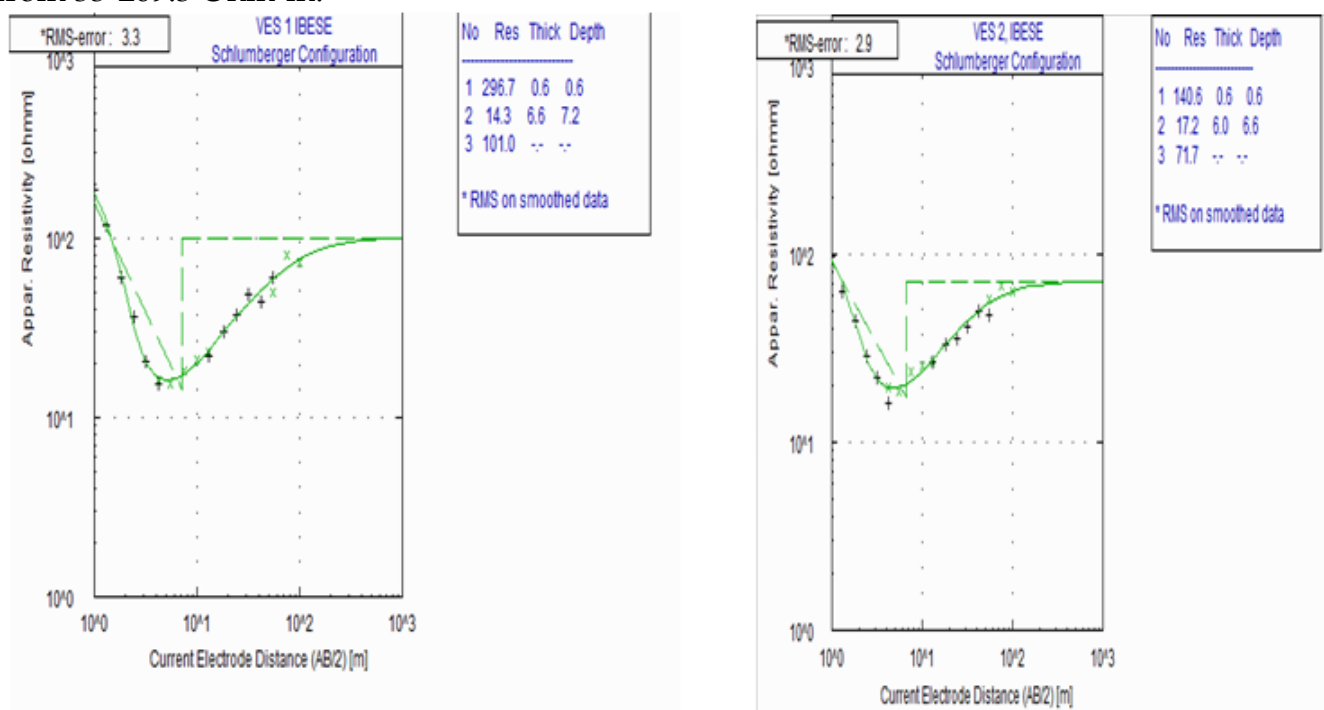

Fig. 4a, Computed iterated graph for VES1

Fig. 4b, Computed iterated graph for VES2

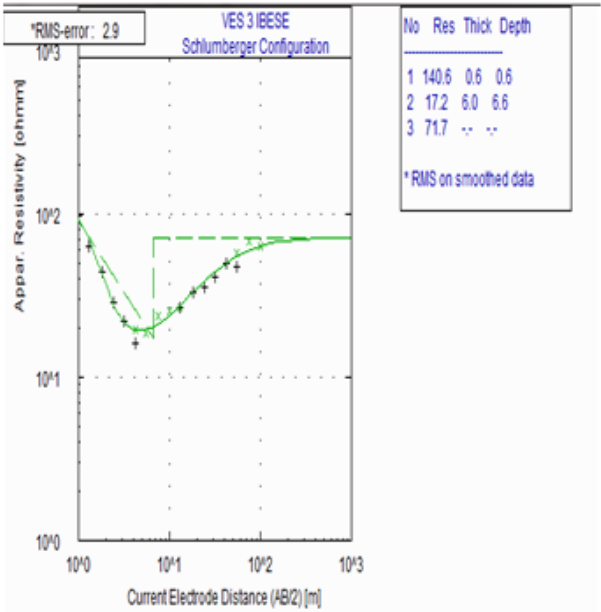

Fig. 4c, Computed iterated graph for VES3

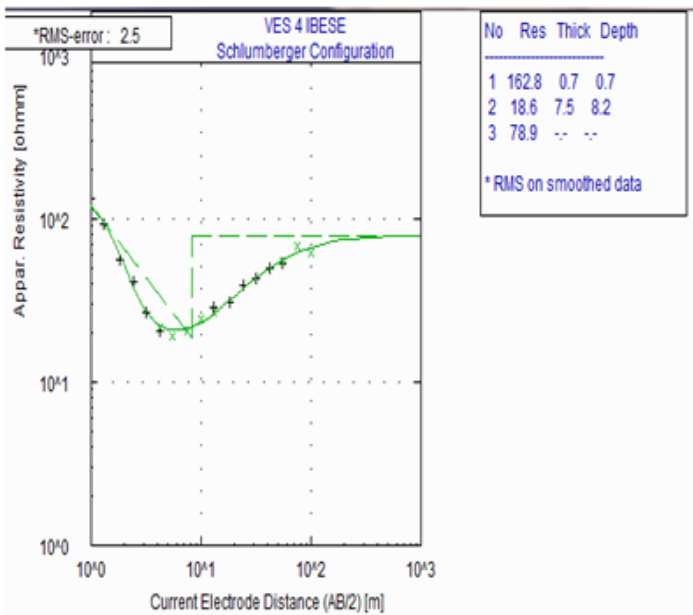

Fig. 4d, Computed iterated graph for VES4 
Asia Pacific Journal of Energy and Environment, Volume 1, No 2 (2014)

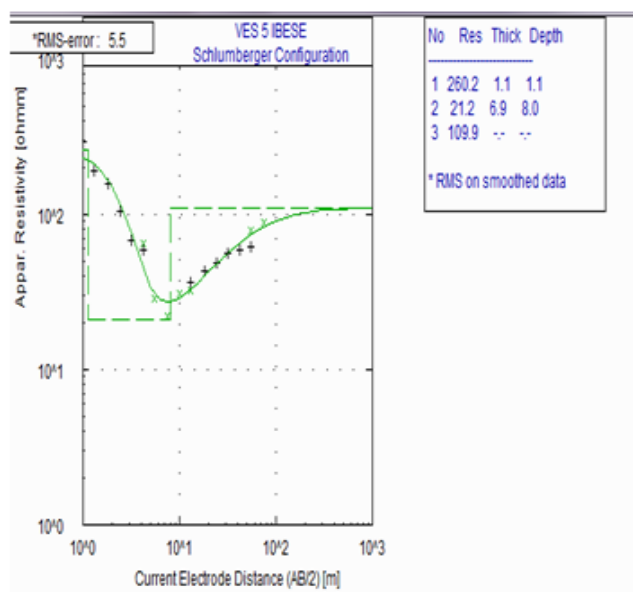

Fig. 4e, Computed iterated graph for VES5

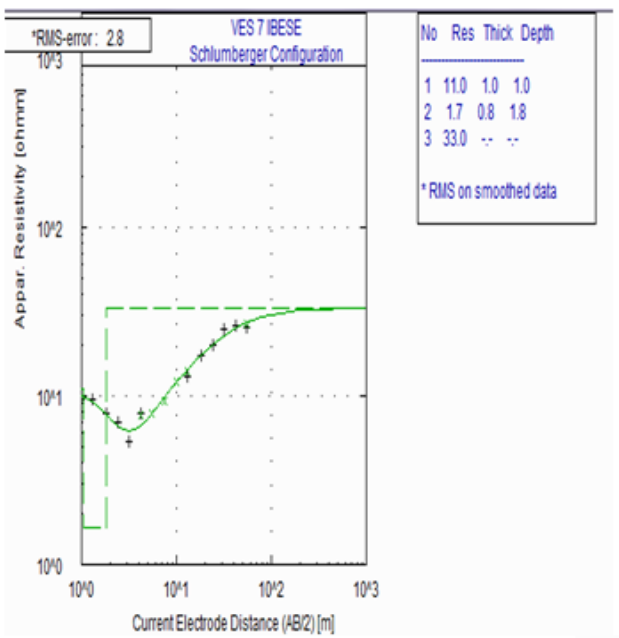

Fig. 4g, Computed iterated graph for VES7

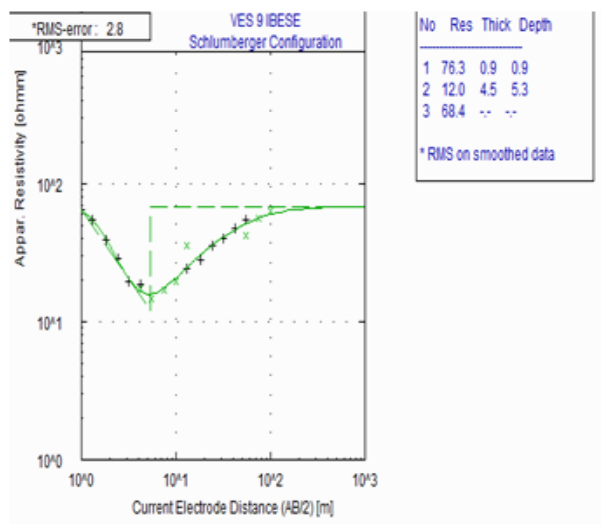

Fig. 4i, Computed iterated graph for VES9

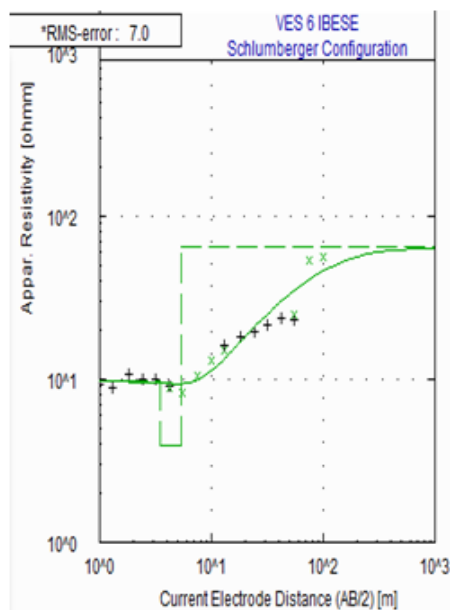

No Res Thick Depth

$\begin{array}{llll}1 & 9.7 & 3.5 & 3.5\end{array}$

$\begin{array}{llll}2 & 3.9 & 19 & 54\end{array}$

$\begin{array}{llll}3 & 64.4 & \cdots & \cdots\end{array}$

'RMS on smoothed data

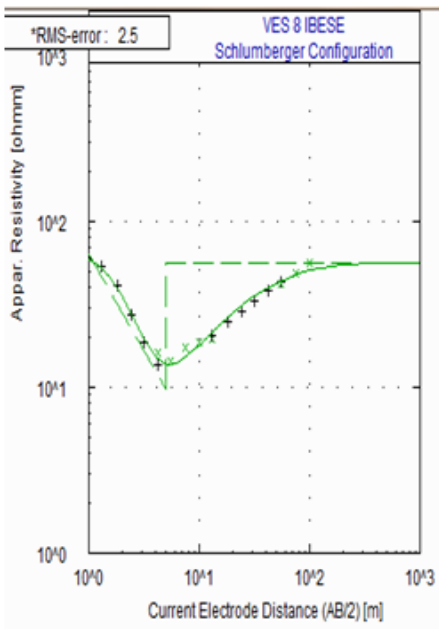

Fig. $4 \mathrm{~h}$, Computed iterated graph for VES8

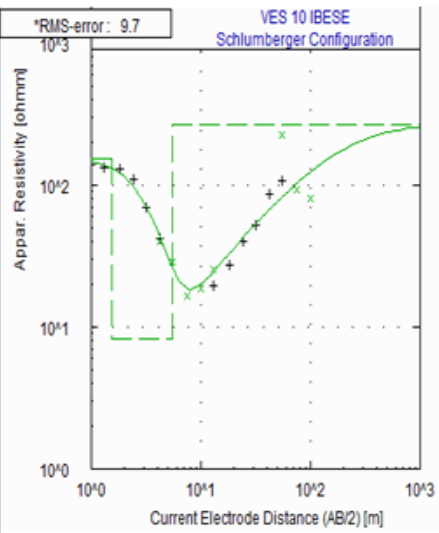

No Res Thick Dept $\begin{array}{llll}1 & 1542 & 1.5 & 1.5\end{array}$

$\begin{array}{lllll}2 & 8.2 & 3.9 & 5.4\end{array}$

$3269.3 \cdots \cdots$

- RuS on smoothed dat:

Fig. 4j, Computed iterated graph for VES10 
Asia Pacific Journal of Energy and Environment, Volume 1, No 2 (2014)

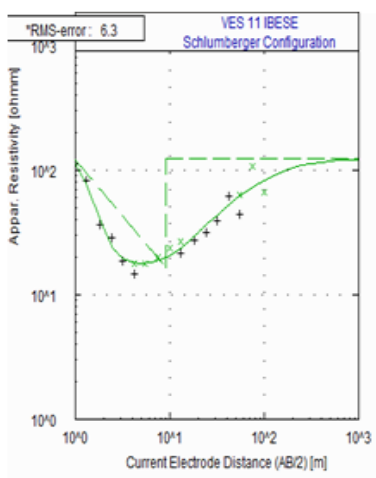

Fig. 4k, Computed iterated graph for VES11

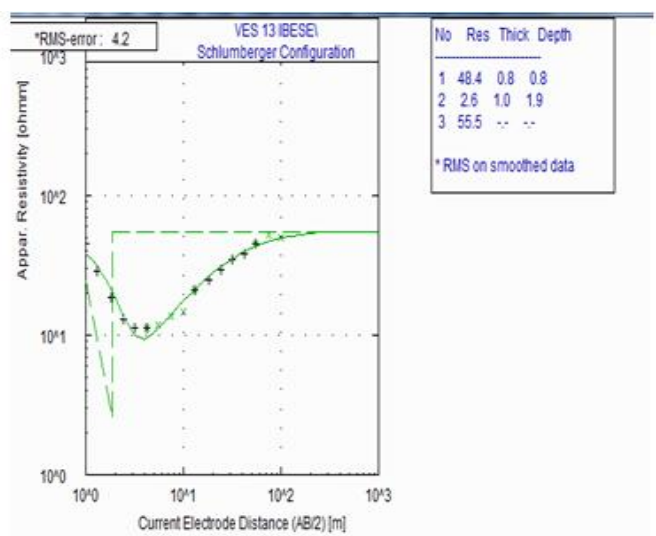

Fig. $4 \mathrm{~m}$, Computed iterated graph for VES13

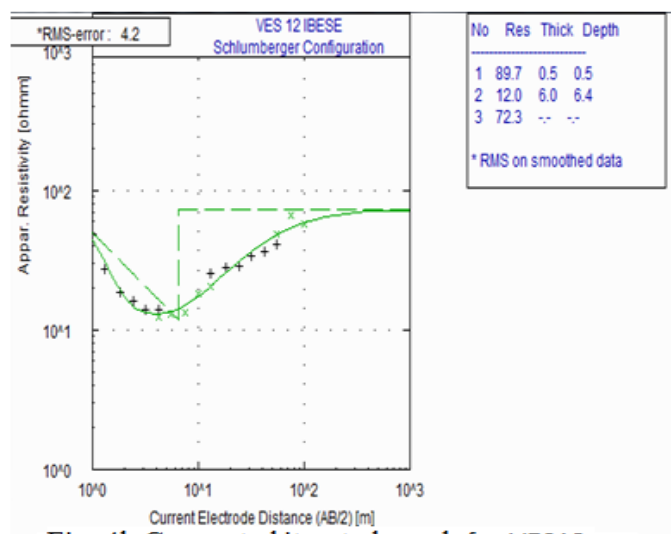

Fig. 41, Computed iterated graph for VES12

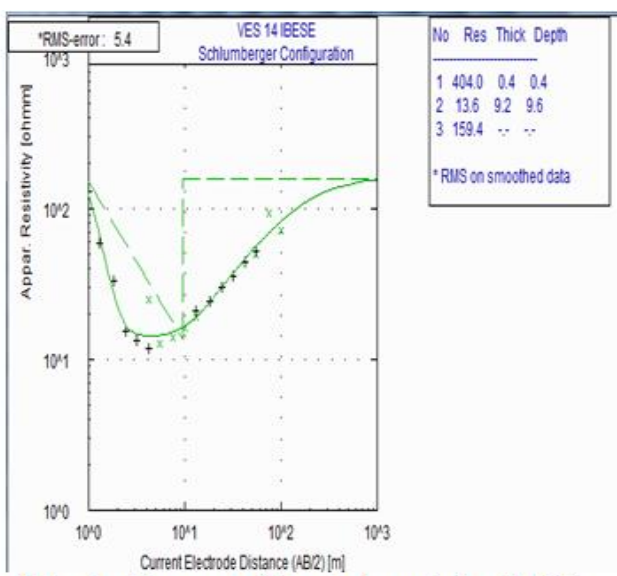

Fig. 4n, Computed iterated graph for VES14

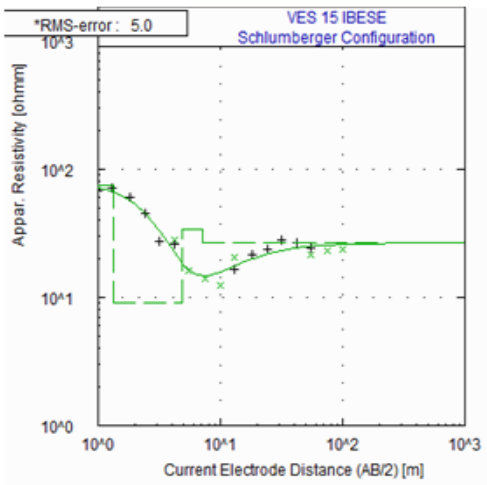

\begin{tabular}{|lccc}
\hline No & Res & Thick Depth \\
\hline 1 & 75.9 & 1.3 & 1.3 \\
2 & 9.1 & 3.6 & 4.9 \\
3 & 34.1 & 2.3 & 7.2 \\
4 & 26.6 & $\because$ & $\because$ \\
" RMS on smoothed data
\end{tabular}

Fig. 4o, Computed iterated graph for VES15 
Asia Pacific Journal of Energy and Environment, Volume 1, No 2 (2014)

Table 5.1: Summary of VES data interpretation

\begin{tabular}{|c|c|c|c|c|c|c|c|}
\hline $\mathrm{S} / \mathrm{N}$ & Layers & $\begin{array}{l}\text { Resistivity } \\
(\Omega \mathrm{m})\end{array}$ & $\begin{array}{l}\text { Thickness } \\
\text { (m) }\end{array}$ & $\begin{array}{l}\text { Depth } \\
(\mathrm{m})\end{array}$ & $\begin{array}{l}\text { Curve } \\
\text { Type }\end{array}$ & $\begin{array}{l}\text { Reflection } \\
\text { Coefficient }\end{array}$ & $\begin{array}{l}\text { Probable } \\
\text { Lithology }\end{array}$ \\
\hline \multirow{3}{*}{$\begin{array}{l}\text { VES } \\
1\end{array}$} & I. & 296.7 & 0.6 & 0.6 & \multirow{3}{*}{$\begin{array}{l}\text { H-Type } \\
\rho_{1}>\rho_{2}<\rho_{3}\end{array}$} & \multirow{3}{*}{0.4245} & Topsoil \\
\hline & II. & 14.3 & 6.6 & 7.2 & & & Clay \\
\hline & III. & 101.0 & & & & & Sandy Clay \\
\hline \multirow{3}{*}{$\begin{array}{l}\text { VES } \\
2\end{array}$} & I. & 296.9 & 0.6 & 0.6 & \multirow{3}{*}{$\begin{array}{l}\text { H-Type } \\
\rho_{1}>\rho_{2}<\rho_{3}\end{array}$} & \multirow[t]{3}{*}{0.7530} & Topsoil \\
\hline & II. & 14.4 & 6.7 & 7.3 & & & Clay \\
\hline & III. & 102.2 & & & & & Limestone \\
\hline \multirow{3}{*}{$\begin{array}{l}\text { VES } \\
3\end{array}$} & I. & 140.6 & 0.6 & 0.6 & \multirow{3}{*}{$\begin{array}{l}\text { H-Type } \\
\rho_{1>\rho_{2}<\rho_{3}}\end{array}$} & \multirow[t]{3}{*}{0.6130} & Topsoil \\
\hline & II. & 17.2 & 6.0 & 6.6 & & & Clay/Limestone \\
\hline & III. & 71.7 & & & & & Sandy clay \\
\hline \multirow{3}{*}{$\begin{array}{l}\text { VES } \\
4\end{array}$} & I. & 162.8 & 0.7 & 0.7 & \multirow{3}{*}{$\begin{array}{l}\text { H-Type } \\
\rho_{1}>\rho_{2}<\rho_{3}\end{array}$} & \multirow[t]{3}{*}{0.6184} & Topsoil \\
\hline & II. & 18.6 & 7.5 & 8.2 & & & Clay \\
\hline & III. & 78.9 & & & & & Limestone \\
\hline \multirow{3}{*}{$\begin{array}{l}\text { VES } \\
5\end{array}$} & I. & 260.2 & 1.1 & 1.1 & \multirow{3}{*}{$\begin{array}{l}\text { H-Type } \\
\rho_{1}>\rho_{2}<\rho_{3}\end{array}$} & \multirow[t]{3}{*}{0.6763} & Topsoil \\
\hline & II. & 21.2 & 6.9 & 8.0 & & & Clay/Limestone \\
\hline & III. & 109.8 & & & & & Sandy clay \\
\hline \multirow{3}{*}{$\begin{array}{l}\text { VES } \\
6\end{array}$} & I. & 10 & 3.5 & 3.5 & \multirow{3}{*}{$\begin{array}{l}\text { H-Type } \\
\rho_{1}>\rho_{2}<\rho_{3}\end{array}$} & \multirow[t]{3}{*}{0.8824} & Topsoil \\
\hline & II. & 4 & 1.9 & 5.4 & & & Clay \\
\hline & III. & 64 & & & & & Clay/Limestone \\
\hline \multirow{3}{*}{$\begin{array}{l}\text { VES } \\
7\end{array}$} & I. & 11.0 & 1.0 & 1.0 & \multirow{3}{*}{$\begin{array}{l}\text { H-Type } \\
\rho_{1}>\rho_{2}<\rho_{3}\end{array}$} & \multirow[t]{3}{*}{0.3542} & Topsoil \\
\hline & II. & 1.7 & 0.8 & 1.8 & & & Clay \\
\hline & III. & 33.0 & & & & & Clay/Limestone \\
\hline \multirow{3}{*}{$\begin{array}{l}\text { VES } \\
8\end{array}$} & I. & 69.2 & 0.9 & 0.9 & H-Type & 0.7031 & Topsoil \\
\hline & II. & 9.9 & 4.1 & 5.0 & $\rho_{1}>\rho_{2}<\rho_{3}$ & & Clay \\
\hline & III. & 56.8 & & & & & Sandy clay \\
\hline VES & I. & 76.3 & 0.9 & 0.9 & H-Type & 0.7015 & Topsoil \\
\hline 9 & II. & 12.0 & 4.5 & 5.3 & $\rho_{1}>\rho_{2}<\rho_{3}$ & & Clay/Limestone \\
\hline & III. & 68.4 & & & i) & & Sandy/Limestone \\
\hline VES & I. & 154.2 & 1.5 & 1.5 & H-Type & 0.9387 & Topsoil \\
\hline 10 & II. & 8.2 & 3.9 & 5.4 & $\rho_{1>}>\rho_{2}<\rho_{3}$ & & Clay \\
\hline & III. & 259.3 & & & & & Limestone \\
\hline VES & I. & 212.9 & 0.5 & 0.5 & H-Type & 0.7635 & Topsoil \\
\hline 11 & II. & 16.6 & 8.5 & 9.0 & $\rho_{1}>\rho_{2}<\rho_{3}$ & & Clay \\
\hline & III. & 123.8 & & 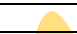 & 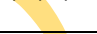 & & Limestone \\
\hline VES & I. & 89.7 & 0.5 & 0.5 & H-Type & 0.7153 & Topsoil \\
\hline 12 & II. & 12.0 & 6.0 & 6.4 & $\rho_{1}>\rho_{2}<\rho_{3}$ & & Clay \\
\hline & III. & 72.3 & & & & & Sandy/Clay \\
\hline VES & I. & 48.4 & 0.8 & 0.8 & H-Type & & Topsoil \\
\hline 13 & II. & 2.6 & 1.0 & 1.9 & $\rho_{1}>\rho_{2}<\rho_{3}$ & 0.9105 & Clay \\
\hline & III. & 55.5 & & & & & Clay/Limestone \\
\hline VES & I. & 404.0 & 0.4 & 0.4 & H-Type & e & Topsoil \\
\hline 14 & II. & 13.6 & 9.2 & 9.6 & $\rho_{1}>\rho_{2}<\rho_{3}$ & & Clay \\
\hline & III. & 159.4 & & 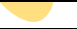 & & 0.8428 & Clay/Sand \\
\hline VES & I. & 75.6 & 1.3 & 1.3 & H-Type & & Topsoil \\
\hline 15 & II. & 9.1 & 3.6 & 4.9 & $\rho_{1}>\rho_{2}<\rho_{3}$ & 0.5787 & Clay \\
\hline & III. & 34.1 & 2.3 & 7.2 & & & Clay/Limestone \\
\hline & IV & 26.6 & & & & & Clay \\
\hline
\end{tabular}

\section{Geoelectric and Lithological Characteristic}

The VES results were used to prepare 2-D geo-electric sections Figures 5a-c. The geo-electric sections revealed three geo-electric/geologic subsurface layers comprising the topsoil (resistivity varies from 11-404 Ohm-m and thickness range from 0.4 to $1.5 \mathrm{~m}$ ); second layer clay/sand horizon (resistivity varies from 2 to $21 \mathrm{Ohm}-\mathrm{m}$ and thickness range from 0.8-9.2m); and the resistivity value of the limestone horizon range from 33-160 Ohm-m.

\section{Isoresistivity and Isopach map of the topsoil}

Figure $6 \mathrm{a}-\mathrm{b}$ shows the 2-D and the 3-D surface of the topsoil. The thickness of the top soil ranges from $0.4-1.5 \mathrm{~m}$ towards the western part of the area. There is a closure of highest thickness up to $3.4 \mathrm{~m}$. The Isoresistivity map shows that the southwestern parts of the study area have the highest resistivity value $380 \mathrm{Ohm}-\mathrm{m}$. The southeastern and Northwestern part showed low resistivity value (<160 Ohm-m). 


\section{Isoresistivity and Isopach map of the second layer}

Figure 6c-d show the Isopach and Isoresistivity maps of the second layer. The Isopach map indicates thickness ranging from $0.8-9.2 \mathrm{~m}$. The map shows the largest thickness in the southwestern part of the study area with thickness up to $9 \mathrm{~m}$ while the Isoresistivity map indicates a resistivity range of 1.7-21.2 Ohm-m.

The highest resistivity values were identified towards the southwestern and southeastern parts of the area up to (200 Ohm-m) and lowest resistivity values were identified in the Northern part of the study area $(\leq 100 \mathrm{Ohm}-\mathrm{m})$.

The high resistivity depicts competent geologic materials, such as sand or clayey sand formation. Very low resistivity suggests clay or sandy clay materials, or water saturated materials, often less competent to support the stability of heavy engineering structures. The depth of the aquifer units range between $0.35 \mathrm{~m}$ and $5.80 \mathrm{~m}$ in the area. Soils below the groundwater tables generally saturated (Coduto, 1998). An important factor often considered in foundation design is the water table and water table fluctuation (Bowles, 1984; Coduto, 1998). In addition, raised water table may create a wet basement or foundation, and consequently engenders instability of the overlying structure (Bowles, 1982; Othman, 2007).
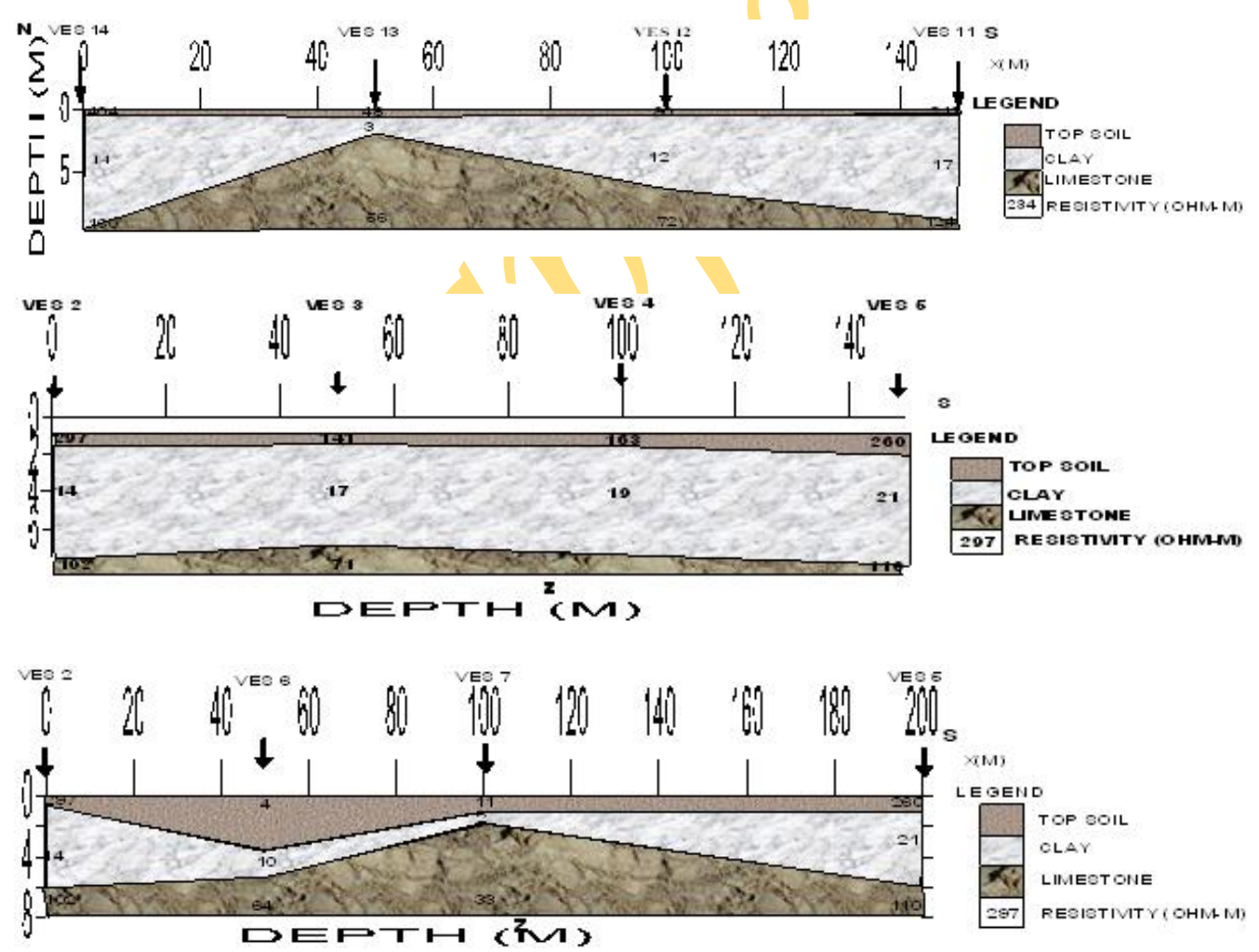

Figure 5 a-c: The Geoelectric section of the VES. 
Asia Pacific Journal of Energy and Environment, Volume 1, No 2 (2014)
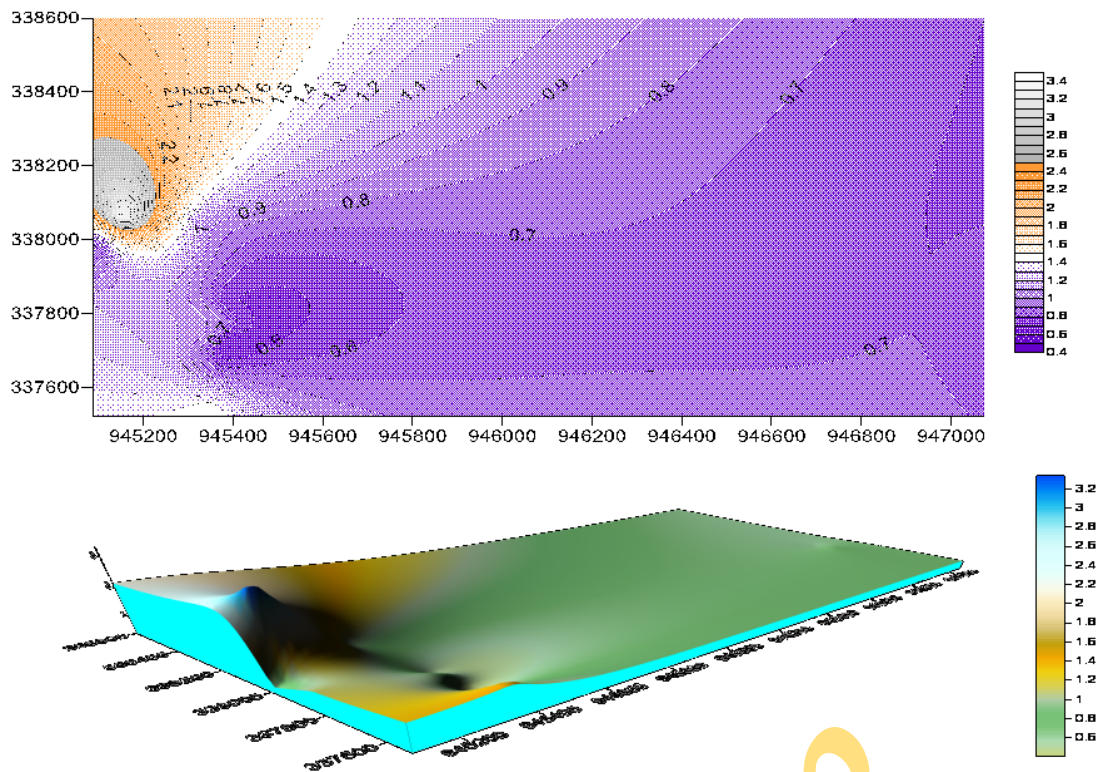

Fig 6a: Isopach map and 3-D surface of the top soil
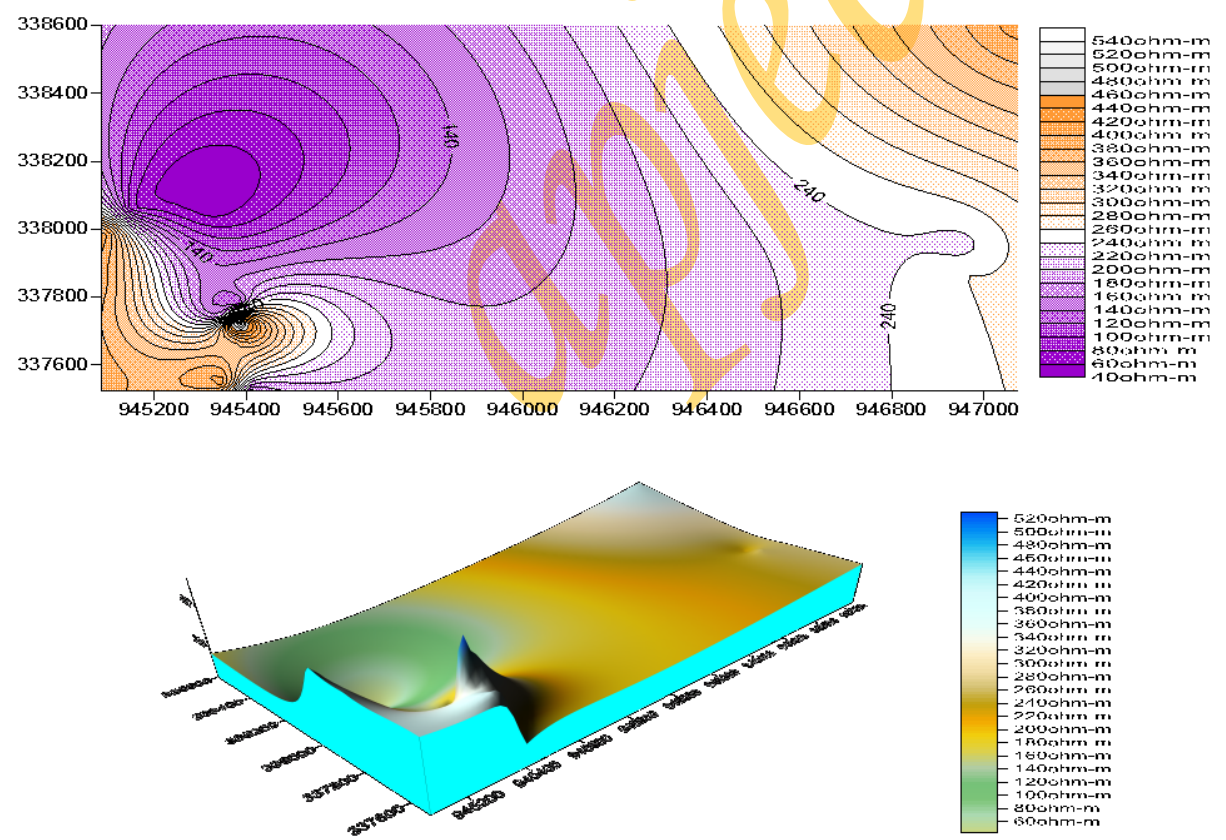

Fig 6b: Isoresistivity map and 3-D surface of the top soil 
Asia Pacific Journal of Energy and Environment, Volume 1, No 2 (2014)
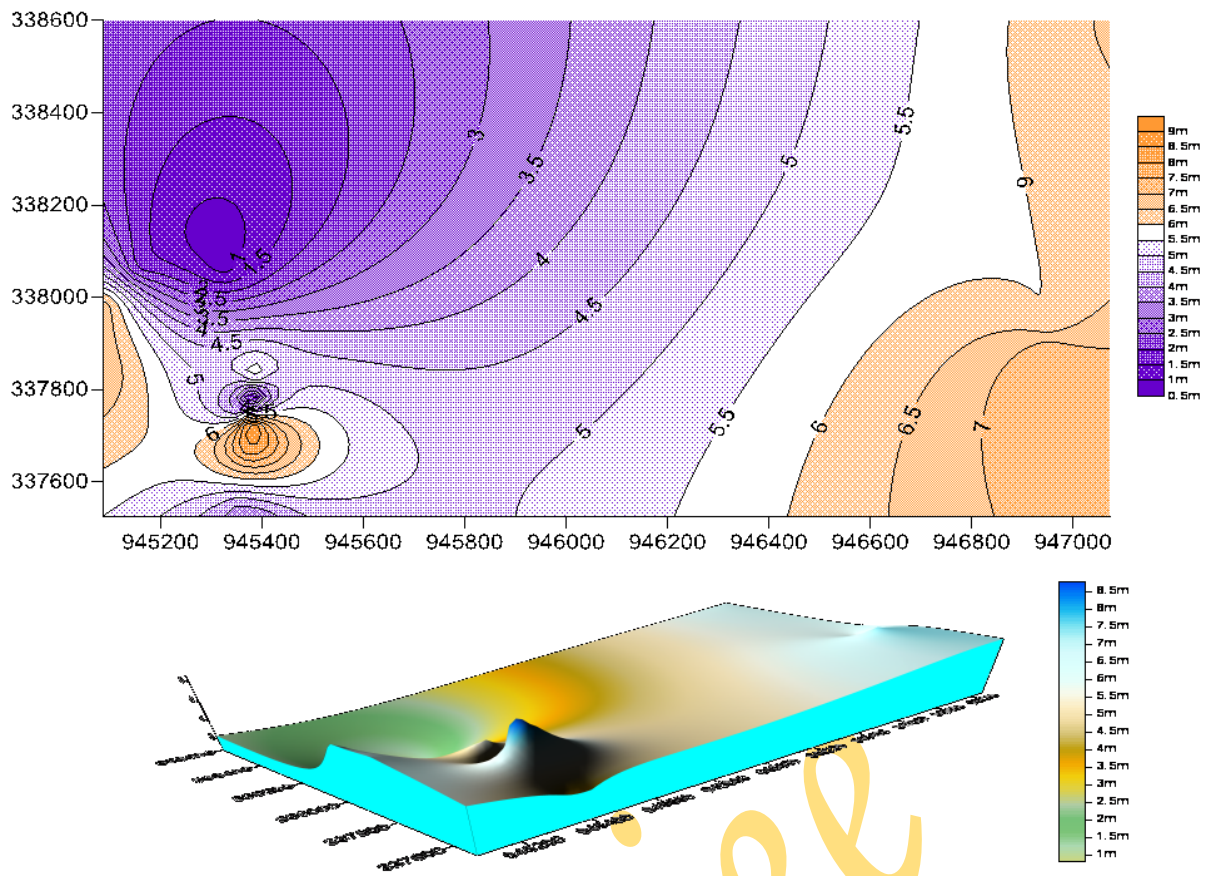

Fig 6c: Isopach map and 3D map of the second layer

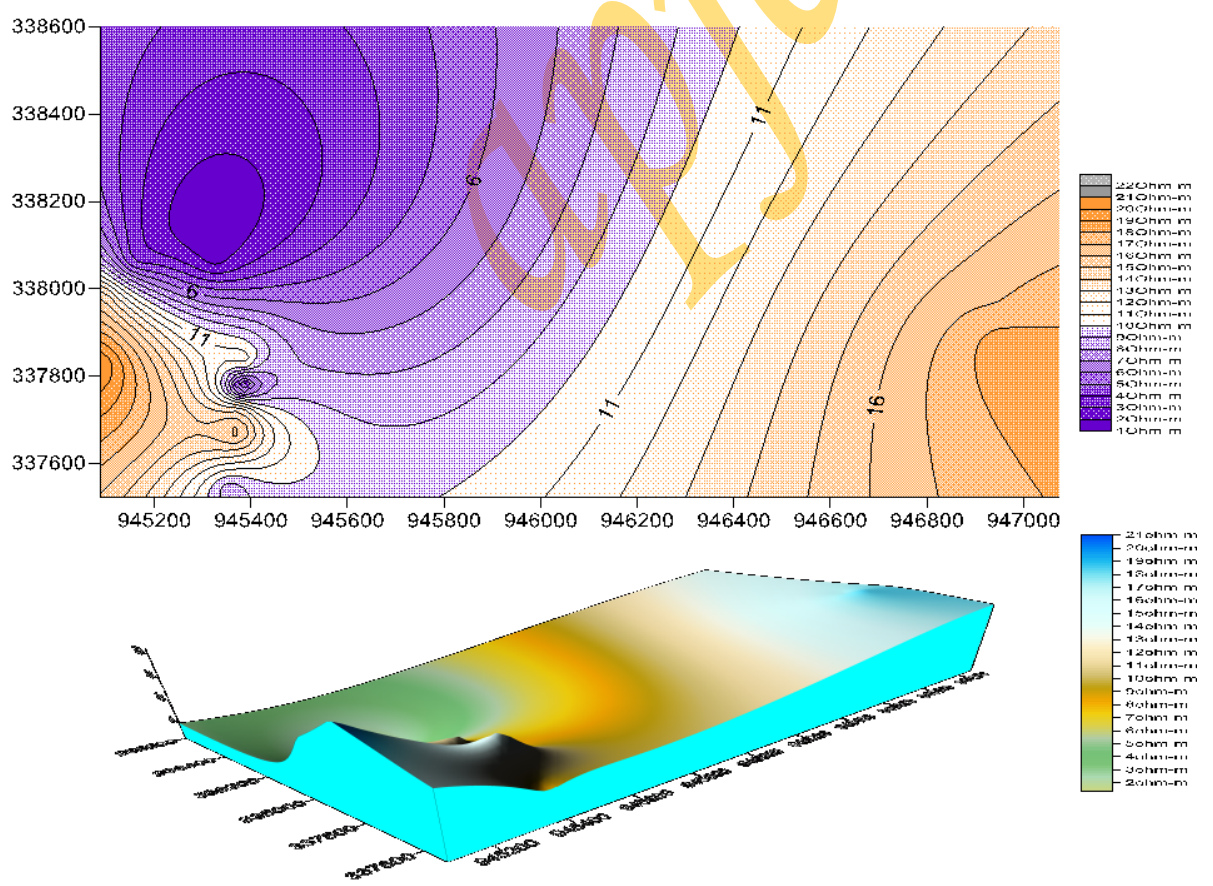

Fig 6d: Isoresistivity and 3D map of the second layer 


\section{CONCLUSION}

The application of Electrical resistivity method has been employed in delineating the various litho units at a proposed building site in Ibese, Southwestern Nigeria. Based on the fifteen VES measurements taken, three major layers were delineated from the study area which comprise topsoil, clayey sand/sandy clay and limestone. The depth of the topsoil range from $0.4 \mathrm{~m}$ at the Southeastern part of the study area to $3.4 \mathrm{~m}$ towards the Western part of the area. The depth of the partially competent bed ranged from $3.4-13.0 \mathrm{~m}$. The first and second layers are highly saturated, and it is rated incompetent. This has been attributed to the waterlogged nature of the site.

Based on the conclusion stated above, the following recommendations are made:

(i) Ground treatment such as dewatering and in-situ compaction should precede use of reinforced concrete during the construction of shallow foundation.

(ii) Depending on the size of structures to be erected, the use of piling may be necessary for the structures to rest directly on the competent bed

(iii) It is important to take into cognizance all other engineering construction criteria that may be relevant considering the waterlogged nature of the site.

(iv) Further geological and geotechnical analysis should be carried out on the soil sample of the study area. Further studies in this respect, could adopt integrated geophysical methods and increase in area of coverage in other to enhance accurate delineation of the stratigraphic layers of the subsurface in the study area.

\section{REFERENCES}

Adeoti, L., Oyedele, K.F., Olowookere, J.O., and Adegbola, R.B. (2008): Assessment of Leachate Effect using Electrical Resistivity Imaging and Hydrochemical methods in a Dumpsite, Lagos, Nigeria, Journal Sci-Tech. \& Environ. ,8(1\&2) 54-61.

Al-Sayed, E. A., El-Qady, G. (2007): Evaluation of Sea Water Intrusion using the Electrical Resistivity and Transient Electromagnetic Survey: Case Study at Fan of Wadi Feiran, Sinai, Egypt, EGM 2007 International Workshop Innovation in EM, Grav and Mag Methods: a new Perspective for Exploration Capri, Italy, April 15 - 18,

Alotaibi, A.M. and AlAmri, A.M. (2007): Ground Water Potentialities of Wadi Malakan- Southern Makkah AlMokadash City, Saudi Arabia, Geophysical Society Journal, 5(1): 101-116.

Barker, R.D. Application of geophysics in groundwater investigations, Water Surv., 1980 84: 489-492.

Bowles, J.E. (1984): Physical and Geotechnical Properties of Soils. McGraw-Hill, London.

Boyce, J.I. and Kaseoglu, B.B. (1996): (Shallow seismic reflection profiling of waste disposal sites. Geoscience Canada, 23(1): 9-21.

Coduto, S.A. (1998): Geotechnical Engineering: Principles and Practices. Prentice Hall Inc. pp 759

Hosny, M.M., EZZ El-Deen, Abdallah, A.A., Abdel Rahman and Barseim, M.S.M. (2005): Geoelectrical Study on the Groundwater Occurrence in the Area Southwest of Sidi Barrani, Northwestern Coast, Egypt, Geophysical Society Journal, 3(1): 109-118.

Mahmoud I.I. Mohamaden., Abuo Shagar S. and Gamal, Abd. Allah. (2009): Geoelectrical Survey for Groundwater Exploration at the Asyuit Governorate, Nile Valley, Egypt, JKAU: Mar. Sci., 2009 Vol. 20, pp: 91-108 A.D. / 1430 A.H.

Mousa, D.A. (2003): The role of 1-D sounding and 2-D resistivity inversions in delineating the nearsurface lithologic variations in Tushka area, south of Egypt, Geophysical Society Journal, 1: 57-64.

Nigm, A.A., Elterb, R. A., Nasr, F.E. and Thobaity, H.M. (2008): Contribution of Ground Magnetic and Resistivity Methods in Groundwater Assessment in Wadi Bany Omair. Holy Makkah Area, Saudi Arabia, Egyptian, Geophysical Society Journal 6(1): 67-79.

Olorunfemi M.O, Idoringie, A.I., Coker, A.T., Babadiya, G.E. (2004): The application of the electrical resistivity method in foundation failure investigation. Global Journal of Geological sciences, Vol.2, 39- 51. 
Omoyoloye, N.A., Oladapo, M.I., and Adeoye, O.O. (2008): Engineering Geophysical Study of Adagbakuja Newtown Development Southwestern Nigeria, Journal of Earth Science, 2(2): 55-63.

Orellana, E. and Mooney, H.M., (1966): Master Tables and Curves for Vertical Electrical Sounding Over Layered Structures, Interciencia, Coastanilla de Los Angeles, 15, Madrid, Spain.

Orellana, E. and Mooney, H.M., (1972): Two and three layer Master curves and Auxiliary Point Diagrams for Vertical Electrical Sounding Using Wenner Arrangement. Interciencia, Madrid.

Othman, A.A.A. (2007): Construed Geotechnical Characteristics of Foundation Beds by Seismic Measurements. J. Geophys. Eng. 2, pp. 126-138.

Oyedele, K.F., Ayolabi, E.A., Adeoti, L. and Adegbola, R.B. (2009): Geophysical and Hydrogeological Evaluation of Rising Groundwater level in the Coastal Areas of Lagos, Nigeria, Bull Eng Geol Environ 68: 137-143.

Zohdy, A.A.R., (1989): A new method for the automatic interpretation of Schlumberger and Wenner sounding curves. Geophysics, 54, 245-253.

Zohdy, A.A.R., (1973): A computer program for automatic interpretation of Schlumberger sounding curves over horizontally stratified media. PB - 232703, National Technical Information Service, Springfield, Virginia, 25p.

Zohdy, A.A.R., (1975): Automatic interpretation of Schlumberger sounding curves using modified Dar Zarrouk functions: U.S. Geol. Surv. Bull., 1313E, 39.

\section{APJEE !!!}

"Speedy publication service, Online archives, Paperless, web-based peer review system, Open access

policy, Indexing in world known citation databases, Global circulation, Broad international readership and authorship, Online submission system, Minimum publication charge" 


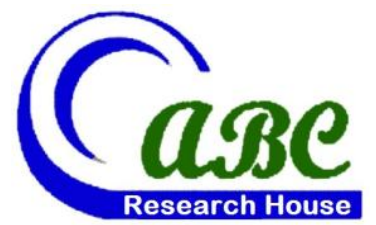

- Rd 4, Shyamoli, Dhaka-1207, Bangladesh

- Off Pantai Dalam, Kuala Lampur, Malaysia

- 3900 Woodhue Place, Alexandria, VA 22309, USA

www.abcreorg.weebly.com / www.abcjournals.net

Asian Business Consortium (ABC) is a multi-disciplinary research, training, publishing, digital library supporting and service house. Though founded in 2010 as the Business and Computing organization of Asia, it was reconstituted as the ABC in 2011. It has been working for creating and nurturing talents in USA, Malaysia and Bangladesh since its inception. As ABC is going global, it intends to open chapters in Australia, Germany, Japan, Pakistan, and other Asian countries in near future. The objectives of consortium are solely centered round the welfare and humane attitude of the founders who enthusiastically took up this noble cause and materialized it with a view to promote research and educational activities for the encouragement of scholars to develop their knowledge, to publish their analysis oriented scientific researches in international Journals, books, the task of organizing workshops, seminars, conferences, training, personality development programs and allied services.

In addition to research activities, ABC provides a good number of scholarships to the poor and meritorious students at various levels of education throughout the world. It plays an important role in the field of research by funding research projects and publishing the research papers. This consortium will unquestionably become the mouth-piece of the dark horses and unacknowledged scholar whose endowed and commendable contributions shall be provided an outlet keeping in mind the greater good of the larger society of the world.

$\mathrm{ABC}$ runs the following international referred journals for creating a platform to share the thoughts of professionals, scholars and academicians throughout the world.

\section{ABC Publications (ABC Journals)}

- Asian Accounting and Auditing Advancement (4A Journal)

- Asian Business Review (ABR)

- Asian Journal of Applied Sciences and Engineering (AJASE)

- Global Disclosure of Economics and Business (GDEB)

- $\quad$ ABC Journal of Advanced Research (ABC-JAR)

- International Journal of Reciprocal Symmetry and Theoretical Physics (IJRSTP)

- American Journal of Trade and Policy (AJTP)

- Asian Journal of Humanity, Art and Literature (AJHAL)

- Malaysian Journal of Medical and Biological Research (MJMBR)

- Asia Pacific Journal of Energy and Environment (APJEE)

- $\quad$ Engineering International (EI)

- $\quad$ ABC Research Alert (Online)

Each journal home page provides specific information for potential authors and subscribers. Open access policy, the quick review process, rich editorial boards and quality publications have already made $A B C$ Journals unique. ABC Journals are published under the direct supervisions of renowned academicians of the world.

Collaboration in Conference: $A B C$ considers high-quality conference papers for publication. Please contact us for detailed information.

Collaboration in Publishing: If you like to start writing a book, propose a new journal or advertise in $\mathrm{ABC}$ journals, please feel free to contact us. 